\title{
Sosialisasi Pemanfaatan Energi Surya Kepada Kelompok Tani dan Nelayan Andalan (KTNA) dalam Rangka Menghadapi Era Revolusi Industri 4.0 di Sektor Pertanian di Kabupaten Paser
}

\author{
Rusda ${ }^{1)}$ Khairuddin Karim ${ }^{2)}$ Cornelius Sarri ${ }^{3)}$ La Bima ${ }^{4)}$ \\ 1,2,3,4) Politeknik Negeri Samarinda \\ rusdadahlan@yahoo.com
}

\begin{abstract}
ABSTRAK: Pada bidang pertanian, Revolusi Industri 4.0 mempunyai pengaruh yang ditandai dengan penggunaan mesin pertanian yang terintegrasi dengan jaringan internet, pengumpulan data mengenai suhu, curah hujan, serangan hama, kecepatan angin serta kandungan-kandungan unsur hara tanah. Sejumlah petani dan nelayan di Kabupaten Paser mengeluhkan tentang masih rendahnya penggunaan teknologi di bidang pertanian. Untuk menjawab hal ini, Pemerintah Kabupaten Paser Kalimantan Timur meluncurkan program di sektor pertanian yang berbasis Teknologi untuk menghadapi Era Revolusi Industri 4.0. Oleh karena itu, untuk mempersiapkan para petani dan nelayan di Kabupaten Paser dalam menghadapi program ini, perlu ditingkatkan kualitasnya. Politeknik Negeri Samarinda bekerjasama dengan Pemerintah Kabupaten Paser mengadakan sosialisasi Penggunaan Solar Cell sebagai salah satu pendukung Revolusi Industri 4.0. Sosialisasi ini diberikan dalam bentuk pemaparan dan demonstrasi penggunaan Solar Cell. Peserta terdiri dari para petani dan nelayan yang tergabung dalam Kelompok Tani dan Nelayan Andalan (KTNA) Kabupaten Paser Kalimantan Timur dan berjumlah 40 petani dan nelayan. Pada sesi terakhir, diberikan kesempatan kepada peserta untuk memberi pertanyaan seputar penggunaan dan pengoperasian Solar Cell. Seluruh pertanyaan dijawab oleh tim sosialisasi dari Politeknik Negeri Samarinda.
\end{abstract}

Kata kunci: Solar Cell, IoT, Pertanian, Kabupaten Paser

ABSTRACT: In the field of agriculture, the Industrial Revolution 4.0 is characterized by the use of agricultural machinery that is integrated with the internet network, collecting data on temperature, rainfall, pest attacks, wind speed and soil nutrient content. A number of farmers and fishermen in Kabupaten Paser complain about the low use of technology in agriculture. To answer this, the Government of Kabupaten Paser Kalimantan Timur launched a program in the technology-based agriculture sector to deal with the Industrial Revolution Era 4.0. Therefore, to prepare farmers and fishermen in Kabupaten Paser in facing this program, quality needs to be improved. Samarinda State Polytechnic (Politeknik Negeri Samarinda) in cooperation with the Kabupaten Paser Government held a socialization on the Use of Solar Cells as one of the supporters of the Industrial Revolution 4.0. This socialization was given in the form of exposure and demonstration of the use of Solar Cells. Participants consisted of farmers and fishermen who are members of Kelompok Tani dan Nelayan Andalan (KTNA) Kabupaten Paser Kalimantan Timur and numbered 40 farmers and fishermen. In the last session, participants were given the opportunity to give questions about the use and operation of the Solar Cell. All questions were answered by the socialization team from Samarinda State Polytechnic

Keywords: Solar Cell, IoT, Agriculture, Kabupaten Paser, Politeknik Negeri Samarinda

\section{PENDAHULUAN}

Era Revolusi Industri 4.0 ini ditandai dengan munculnya pengaruh pengunaan Teknologi Internet of Think (IoT) dan penggunaan sumber-sumber energi hijau seperti Solar Cell. Teknologi Solar Cell dan pemanfaatannya saat ini sudah meluas ke berbagai 
sektor bidang kehidupan dan tidak terkecuali di sektor pertanian. Hal ini disebabkan oleh adanya beberapa keunggulan dari Solar Cell sebagai sebuah sumber energi, seperti: ramah lingkungan, mudah dalam pengoperasiannya, mudah dalam perawatan, dan dapat di-interkoneksi dengan sumber-sumber energi lain jika dipasang sebagai sumber energi listrik.

Bidang pertanian, Revolusi Industri 4.0, ditandai dengan munculnya mesinmesin pertanian yang terintegrasi dengan jaringan internet, penggunaan Personal Computer (PC) untuk menganalisis suhu dan cuaca untuk keperluan pengolahan pertanian, otomatisasi teknik pertanian untuk meningkatkan kualitas dan kuantitas pertanian, pemanfaatan Solar Cell untuk kebun-kebun, irigasi, dsb.

Beberapa contoh pemanfaatan Solar Cell untuk peningkatan produksi serta efisiensi, seperti yang digambarkan berkut:

\section{Smart Green House}

Salah satu tujuan dari rumah kaca pertanian PV adalah untuk memperoleh pendapatan pertanian yang lebih tinggi dengan secara fleksibel menciptakan lingkungan yang cocok untuk pertumbuhan tanaman. Misalnya, petani dapat menanam tanaman bernilai tambah tinggi seperti produk pertanian organik dan bibit langka dan mahal (Xue, 2017). Gambar 1 menunjuklkan sebuah kebun di samping sebuah Sistem Agrivoltaic.

\section{Smart Irrigation System}

Pompa yang digunakan untuk transportasi air dilengkapi dengan Solar Cell. Energi matahari yang diserap oleh Solar Cell kemudian diubah menjadi energi listrik melalui generator yang kemudian menyuplai motor listrik penggerak pompa. Sebagian besar sistem pompa tradisional terutama yang menggunakan mesin diesel sebagai sumber listriknya atau dengan jaringan lokal. Namun, kedua mode operasi ini mempunyai kekurangan dibandingkan dengan yang menggunakan Solar Cell. Banyak daerah pedesaan, terutama di negara berkembang, akses untuk mendapatkan energi listrik tidak selalu terjamin. Dalam hal ini, petani tidak dapat mengandalkan sistem irigasi tradisional. Dengan demikian, agar suplai listrik motor pompa tetap terjamin, penggunaan Solar Cell menjadi alternatif yang paling cocok.

\section{Automatic Tractor}

Sebuah teknologi dimana petani dapat mengontrol traktor dengan menggunakan remote, bahkan dapat dikoktrol dari rumah. Jika dilihat dari manfaatnya, memang Revolusi Industri 4.0 memiliki dampak yang baik bagi petani, pun bagi masyarakat umum yang dapat mengonsumsi hasil pertanian yang berkualitas.

Di sisi lain ada beberapa tantangan yang harus dihadapi dengan adanya penerapan Revolusi Industri 4.0 di bidang pertanian, yaitu antara lain.

1. Perlunya perbaikan infrastruktur

Ciri utama Era Revolusi Industri 4.0 adalah pemanfaatan internet dalam beraktifitas dan hal ini harus didukung oleh infrastruktur jaringan yang memadai. 
Seperti diketahui bahwa belum semua daerah di Indonesia sudah dijangkau oleh Jaringan internet dan umumnya yang berada di daerah pedalaman dengan penduduk bermata pencaharian sebagai petani atau nelayan. Hal ini menjadi tantangan bagi semua pihak khususnya jika ingin mengembangkan sektor pertanian menuju Era Revolusi 4.0.

2. Perlunya biaya

Umumnya suatu teknologi berharga mahal dan tentu akan sulit dijangkau oleh masyarakat yang berpenghasilan rendah sementara pada umumnya masyarakat yang bermatapencaharian petani atau nelayan, berpenghasilan rendah. Namun demikian, beberapa daerah pertanian yang berdekatan dengan kota-kota besar, umumnya telah memasuki Era Revolusi 4.0.

3. Petani yang belum melek teknologi

Walaupun Revolusi Industri 4.0 difokuskan terhadap petani milenial namun pentingnya teknologi juga berpengaruh terhadap petani yang bukan milenial, sebab petani Indonesia saat ini masih banyak tamatan SD dan SMP yang masih berusia produktif, mereka juga masih berperan dalam dunia pertanian. Walaupun demikian pemerintah dalam hal ini Departemen Pertanian menggalakkan penyuluhan dan regenerasi petani muda sehingga jumlah petani yang berusia di bawah 25 tahun, saat ini mengalami kenaikan sebesar $148 \%$ selama 5 tahun terakhir. Petani muda inilah yang akan berperan nantinya (Tabloid Sinartani, 07 Oktober 2019).

Sebuah analisis pada situasi terkini di bidang pertanian dalam hal pemanfaatan energi surya memperlihatkan secara jelas perbedaan situasi antara negara industri dengan negara berkembang. Perbedaan tersebut mempunyai pengaruh yang besar terhadap kemungkinan penggunaan energi matahari dalam hal pemanfaatannnya dibidang pertanian. Peningkatan hasil panen, perbaikan kualitas produk dan pengurangan penyusutan secara langsung dihubungkan dengan ketersediaan energi. Ketersediaan energi yang berasal dari bahan bakar fosil yang semakin lama semakin berkurang, di mana untuk sebagian Negara berkembang masih import, adalah sangat mahal harganya di daerah pedesaan. Oleh karena itu penyediaan energi yang berasal dari sumber-sumber alternatif adalah sangat mendesak.

Pembangkit daya listrik dengan memanfaatkan energy matahari (Solar Cell) pada awalnya dikembangkan untuk menyediakan listrik untuk peralatan-peralatan yang ada di daerah terpencil atau ruang yang tidak bisa atau tidak mungkin dijangkau oleh sumber konvensional seperti kendaraan-kendaraan luarngkasa. Terkait dengan karakteristik Solar Cell yang ramah lingkungan, aplikasi dan produksi dari Solar Cell terus dikembangkan dari tahun ke-tahun.

\section{PERMASALAHAN}

Desa Sepulang, Kecamatan Tana Paser Kabupaten Paser, penghasilan utama masyarakat setempat adalah bertani sawah dan kebun sawit. Terdapat kendala yang 
selama ini sangat sulit untuk diatasi yaitu jika musim hujan akan terjadi banjir dan jika musim kemarau akan terjadi kekeringan. Sarana dan prasarana pertanian belum memadai di daerah ini, sebagian akses ke daerah masih sangat buruk sehingga perlu pembangunan dengan pola swakarsa. Perlu bantuan alat-alat pertanian yang lebih modern agar produktivitas pertanian rakyat semakin meningkat.

Kondisi demikian perlu diperbaiki dari berbagai segi dan salah satunya adalah dengan mengenalkan tentang pemanfaatan teknologi Solar Cell yang nantinya dapat dimanfaatkan sebagai sumber energi listrik untuk alat-alat pertanian mereka, seperti alat perontok gabah, pompa-pompa irigasi, pengering gabah, dsb. Pengenalan ini dilakukan dalam bentuk sosialisasi yang ditujukan kepada petani atau nelayan yang ada di Kabupaten Paser.

Adapun tujuan pelaksanaan kegiatan sosialisasi pemanfaatan teknologi Solar Cell kepada petani ini adalah sebgai berikut:

1. Masyarakat mengenal manfaat Energi Surya/matahari;

2. Masyarakat mengenal fungsi dari Solar Cell;

3. Masyarakat mengenal bagian-bagian atau komponen dari Solar Cell;

4. Masyarakat mengenal cara pengoperasian Solar Cell;

5. Masyarakat mengenal cara pemeliharaan Solar Cell; dan

6. Masyatakat mengetahui manfaat Solar Cell untuk pertanian.

\section{METODE PELAKSANAAN}

Pelaksanaan sosialisasi pemnfaatan teknologi Solar Cell ini dilaksanakan dalam 2 (dua) tahap, yaitu sebagai berikut.

1. Penyajian materi, yaitu memberikan materi tentang manfaat energi surya, fungsi Solar Cell, komponen-komponen Solar Cell, cara pengoperasian dan pemeliharaan Solar Cell, dan peran Solar Cell di sektor pertanian.

2. Demonstrasi, yaitu melakukan demonstrasi pengoperasian dan cara pemeliharaan sebuah modul Solar Cell. Demonstrasi ini juga memperlihatkan cara merakit instalasi Solar Cell.

\section{PELAKSANAAN}

Kegiatan Sosialisasi Pemanfaatan Energi Surya kepada Petani dan nelayan di Kabupaten Paser dilaksanakan pada tanggal 27 November 2019 di Ruang Aula Pendopo Kabupaten Paser yang dihadiri oleh anggota Kontak Tani dan Nelayan Andalan (KTNA) Kabupaten Paser. Selain itu, acara juga dihadiri oleh beberapa unsur Forkopimda (Forum Komunikasi Pemerintah Daerah) Kabupaten Paser. Acara sosialisasi ini, dirangkaikan dengan acara Rembug Madya anggota KTNA dan sekaligus pembentukan Pengurus Baru KTNA Kabupaten Paser. 

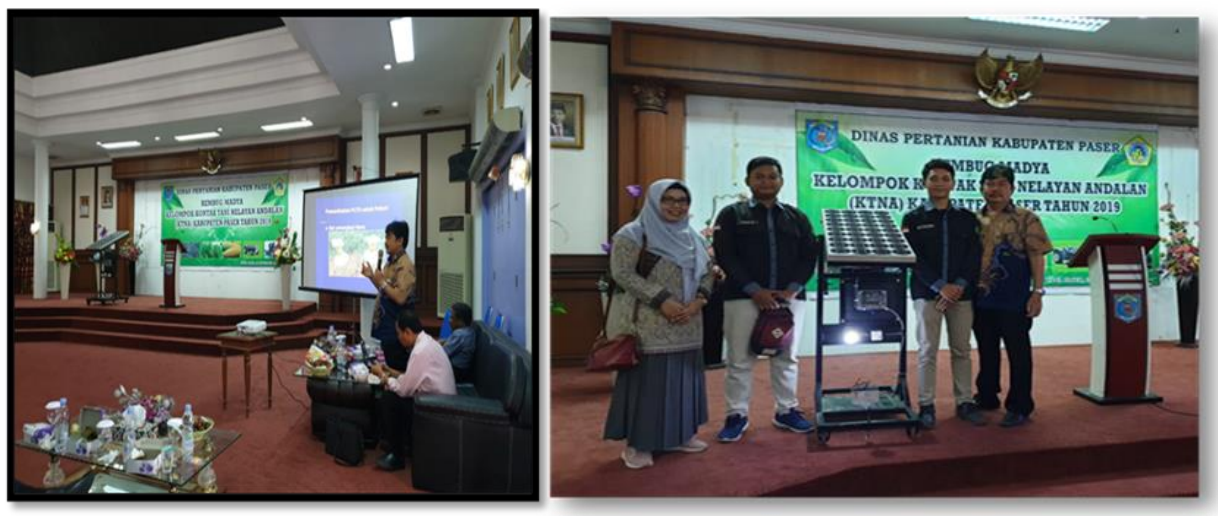

Gambar 1. Kegiatan Sosialisasi dan Foto Tim Pembuat Modul Solar Cell.

Sosialisasi diadakan dalam bentuk ceramah dan disampaikan oleh Tim Pengabdian kepada Masyarakat POLNES yang terdiri dari 4 (empat) dosen, yaitu:

1. Rusda, S.T., M.T selaku Ketua Tim. Materi: Teknologi di bidang Pertanian;

2. Khairuddin Karim, S.T., M.T selaku anggota Tim. Materi: Pengenalan tentang Solar Cell

3. Ir. Cornelius Sarri, S.T., M.T selaku Anggota Tim. Materi: Cara pengoperasian dan pemeliharaan Solar Cell.

4. Drs.La Bima, M.Sc. selaku Anggota Tim. Materi: Potensi Energi Surya.

Setalah penjelasan/ceramah oleh tim, diadakan demonstrasi cara merakit, mengoperasikan, dan memelihara sebuah modul Solar Cell yang dibantu oleh tim teknisi yang berasal dari mahasiswa Politeknik Negeri Samarinda Jurusan Teknik Elektro, yaitu Rusaldi Hendra Angkatan 2016/2017, dan Yogi Prastaka Endra Angkatan 2016/2017.

\section{HASIL DAN LUARAN}

Pada sesi terakhir, diberi kesematan kepada para peserta sosialisasi untuk bertanya terkait dengan Solar Cell dan pemnafaatannya di sektor pertanian. Beberapa pertanyaan yang disampaikan oleh peserta, antara lain.

1. Untuk membangun sebuah Solar Cell atau Pembangkit Listrik Tenaga Surya (PLTS) berapa anggaran yang dibutuhkan dan bagaimana kalau para petani ini bekerjasama dalam membangun PLTS yang sesuai di lahan pertanian?

2. Bagaimana cara pemeliharaan PLTS dan apakah modul yang rusak bahan semikonduktornya masih bisa diperbaiki ?

3. Bagaimana prinsip kerja dari alat penangkap hama yang menggunakan solar cell?

4. Bagaimana prinsip kerja dari alat pengering menggunakan solar cell ?

5. Bagaimana prinsip kerja alat pembunuh tikus berdasarkan tegangan kejut, apakah di Politeknik bisa membuat alat semacam itu dan alat ini sudah ada di Jepang. 
Jawab:

1. Ir. Cornelius Sarri, M.T.: Untuk membangun sebuah Solar Cell atau Pembangkit Listrik Tenaga Surya (PLTS), sangat tergantung pada besar daya yang diinginkan. Namun komponen utama dari sebuah PLTS yang harus dibeli adalah panel modul yang berbahan semi-konduktor yang dilengkapi dengan beberapa komponen seperti inverter. Jika digunakan di Sistem Off Grid, umumnya dilengkapi dengan Battery yang akan berfungsi pada malam hari. Harga battery juga termasuk mahal untuk saat ini.

2. Khairuddin Karim, S.T., M.T., Pada dasarnya Perguruan Tinggi membutuhkan mitra untuk menerapkan ilmu dan teknologi yang dikembangkan di Kampus. Salah satu kegiatan yang dilaksanakan tiap tahun adalah bentuk seperti Pengabdian Masyarakat ini. Kegiatan ini bertujuan untuk menerapkan ilmu dan pengetahuan atau teknologi yang di kembangkan di kampus. Oleh karena itu, perlu ada tindaklanjut setelah kegiatan ini selesai.

3. Ir. Cornelius Sarri, M.T., Pemeliharaan sebuah PLTS sangat mudah dilaksanakan. Kendala utamanya hanyalah karena posisi Panel itu berada di atas sehingga perlu alat bantu (tangga). Bagian utama yang harus selalu diperhatikan adalah permukaan panel surya yang berbahan mika/kaca. Alat yang digunakan juga adalah alat biasa untuk pembersihan seperti lap. Namun tetap diperhatikan, jangan sampai permukaan panel tergores, hal ini akan berakibat turunya efisiensi dari panel. Selain panel, yang perlu diperhatikan juga adalah Battery/aki jika sistemnya menggunakan battery/aki. Pemeliharaan aki seperti pemeliharaan aki biasa namun yang penting adalah harus rutin dibersihkan. Bisa dibuatkan jadwal berkala seperti pemeliharaan harian, mingguan, bulanan, atau tahunan. Jika terjadi kerusakan di bagian bahan semikonduktornya, maka panel itu seharusnya diganti mengingat komponen yang ada dibawah permukaan kaca dari panel surya sudah terakit secara massive dan sangat sulit untuk diperbaiki.

4. Ir. Cornelius Sarri, M.T., : Prinsip kerja penangkap hama menggunakan Solar Cell adalah; Pinsip kerja dari alat ini yakni saat matahari tenggelam di sore hari, lampu akan menyala secara otomatis karena energi listrik yang dipancarkan bersumber dari bateri, modul (panel surya) akan merubah energy matahari menjadi energy listrik dan kemudian menyimpannya di baterei, setelah itu dikonversikan listrik searah (dc) menjadi listrik bolak balik (ac) untuk dialirkan pada lampu light trap ( T8 ultraviolet).

5. Alat ini memanfaatkan energi radiasi matahari untuk menggerakkan kipas yang mendorong udara di dalam ruang pengeringan. Selain itu, penutup alat pengering yang terbuat dari bahan plastik polyethilen yang transparan juga membantu mempercepat proses pengeringan. Aliran udara di dalam alat pengering akan menghilangkan air dari dalam ruang pengering dan dikeluarkan melalui lubang pengeluaran. 

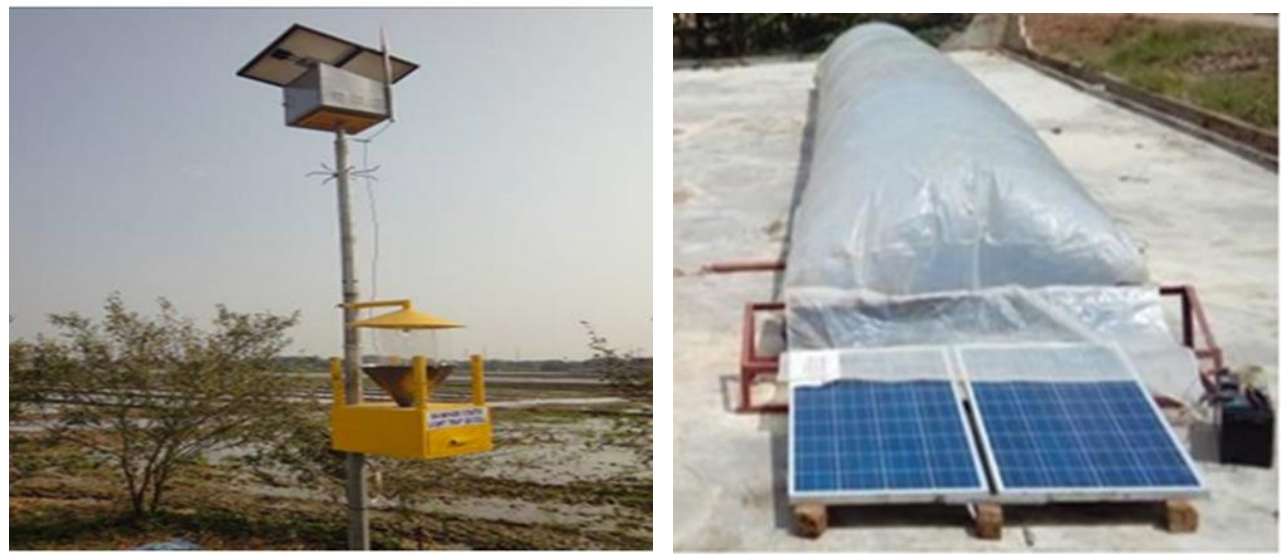

Gambar 2. Contoh Alat Pemanfaatan Solar Cell.

Setelah kegiatan ini selesai, peserta mendapatkan pengetahuan tentang manfaat Energi Surya/matahari; fungsi dari Solar Cell; bagian-bagian atau komponen dari Solar Cell; cara pengoperasian Solar Cell; cara pemeliharaan Solar Cell;dan manfaat Solar Cell untuk pertanian.

\section{KESIMPULAN}

Beberapa kesimpulan dapat ditarik setelah kegiatan ini sehingga dapat memberikan manfaat. Kesimpulan yang dapat diambil antara lain.

1. Kegiatan sosialisasi tentang pemanfaatan Energi Surya ini berjalan lancar dan diikuti oleh seluruh peserta sampai selesai;

2. Peserta mendapatkan pengetahuan dasar tentang Solar Cell. Pengetahuan dasar tersebut meliputi: prinsip kerja solar cell, bagian-bagian atau komponen-kompoene dari Solar Cell, dan manfaat Solar Cell pada bidang Pertanian;

3. Peserta menginginkan peran Perguruan Tinggi, khususnya Politeknik Negeri Samarinda untuk mengaplikasikan teknologi Solar Cell di bidang Pertanian khususnya di Kabupaten Paser.

\section{DAFTAR PUSTAKA}

Agrivol Taics Farming Solar Panels. (online). (https://www.futurity.org),, diakses tanggal 28 Maret 2020.

Future of Farming Driverless Tractors Ag Robots. 2016. (online). (https://www.cnbc.com)., diakses tanggal 15 Mei 2020.

Petani di Kabupaten Paser Perlu Sarana Pertanian. (online). (https://korankaltim.com)., diakses tanggal 25 Mei 2020.

Solar Powered Irrigation A Solution To Water Management In Agriculture. (online). (http://www.renewableenergyfocus.com)., diakses tanggal 23 Februari 2020.

Tabloid "Sinartani”. 2019. Acsess October $07^{\text {th }} 2019$. 
Volume 4, Nomor 2, September 2020

Xue, J. 2017. Photovoltaic agriculture-New Opportunity for applications in China. Elsevier. 